\title{
Assessment of functional outcome of patients undergoing surgery for chronic pancreatitis: A prospective study
}

\author{
Pagadala Naga Balaji Nitesh ${ }^{1}$, Vutukuru Venkatarami Reddy ${ }^{1}$, Sivarama Krishna Gavini ${ }^{1}$, \\ Suresh Vaikkakara ${ }^{2}$, Chandramaliteeswaran Chandrahasan ${ }^{1}$, Musunuru Bramheswara Rao ${ }^{1}$, \\ and Dasari Varun ${ }^{1}$
}

\author{
Departments of ${ }^{1}$ Surgical Gastroenterology and ${ }^{2}$ Endocrinology, \\ Sri Venkateswara Institute of Medical Sciences (SVIMS), Tirupati, India
}

\begin{abstract}
Backgrounds/Aims: This study was done with the aim of assessing impact of surgery for chronic pancreatitis on exocrine and endocrine functions, quality of life and pain relief of patients. Methods: 35 patients of chronic pancreatitis who underwent surgery were included. Exocrine function assessed with fecal fat globule estimation and endocrine function assessed with glycated haemoglobin ( $\mathrm{HbA1C}$ ), fasting plasma glucose (FPG), Insulin and C-peptide levels. Percentage (\%) beta cell function by homeostatic model assessment (HOMA) was determined using web-based calculator. Quality of life (QOL) and pain assessment was done using Short form survey (SF-36) questionnaire and Izbicki scores respectively. Follow up done till 3 months following surgery. Results: Endocrine insufficiency was noted in $13(37 \%)$ patients in the postoperative period compared to $17(49 \%)$ patients preoperatively $(p=0.74)$. Exocrine insufficiency was detected in $11(32 \%)$ patients postoperatively compared to $8(23 \%)$ patients preoperatively, with denovo insufficiency noted in $3(8 \%)$ patients $(p<0.05)$. The mean Izbicki score at 3 months postoperatively was remarkably lower compared to preoperative score $(29.3 \pm 14.3$ vs. $60.6 \pm 12.06 ; p<0.05)$. QOL at 3 months following surgery for chronic pancreatitis was significantly better than preoperative QOL $(50.24 \pm 22.16$ vs. $69.48 \pm 20.81 ; p<0.05)$. Conclusions: Significant pain relief and improvement in quality of life among patients of chronic pancreatitis following surgery. However, worsening of exocrine function with only clinical improvement of endocrine function was also noted. (Ann Hepatobiliary Pancreat Surg 2020;24:162-167)
\end{abstract}

Key Words: Chronic pancreatitis surgery; Exocrine function; Endocrine function; Pain relief; Quality of life

\section{INTRODUCTION}

Chronic pancreatitis is a chronic benign disease often characterized by recurrent episodes of abdominal pain accompanied by progressive pancreatic exocrine and endocrine insufficiency. ${ }^{1}$ Although the disease was first described by Friedrich in 1878 , there is yet incomplete understanding of the pathophysiology and natural history of the disease. The management of patients with chronic pancreatitis remains a challenge because of the limited understanding of the pathophysiological process of the disease, the unpredictability of clinical evolution and the controversies between diagnostic criteria and therapeutic options.

Debilitating abdominal pain remains the most common presentation and indication for surgery in patients with chronic pancreatitis. The precise mechanism underlying the abdominal pain is uncertain. It may be related to ductal hypertension, ${ }^{2}$ increased parenchymal pressure, perineural inflammation $^{3}$ or as a complication of the disease. Surgery has been the mainstay of treatment in these patients with intractable pain unresponsive to medical or endoscopic therapy. ${ }^{4}$

Preoperative tests of pancreatic function help to assess the severity of disease and to guide perioperative metabolic requirements. ${ }^{5}$ After operation, impaired exocrine and endocrine function can lead to malnutrition and other risks, including death. ${ }^{6}$ Pancreatic function testing is thus important for proper patient management.

Received: November 5, 2019; Revised: January 21, 2020; Accepted: January 21, 2020

Corresponding author: Pagadala Naga Balaji Nitesh

Department of Surgical Gastroenterology, Sri Venkateswara Institute of Medical Sciences (SVIMS), Tirupati 517507, India Tel: +91-8179705152, Fax: +91-949-3541451, E-mail: nitesh.pagadala@gmail.com

Copyright (C) 2020 by The Korean Association of Hepato-Biliary-Pancreatic Surgery

This is an Open Access article distributed under the terms of the Creative Commons Attribution Non-Commercial License (http://creativecommons.org/ licenses/by-nc/4.0) which permits unrestricted non-commercial use, distribution, and reproduction in any medium, provided the original work is properly cited. Annals of Hepato-Biliary-Pancreatic Surgery • pISSN: 2508-5778 - elSSN: 2508-5859 
To our knowledge, very few reports have yet focused solely on the effect of operations on pancreatic exocrine and endocrine function in chronic pancreatitis with varied results. Therefore, this study is being done to assess the effect of surgery in chronic pancreatitis on pain relief, exocrine and endocrine functions and quality of life of the patients.

\section{MATERIALS AND METHODS}

A prospective study was done in the department of surgical gastroenterology, Sri Venkateswara institute of medical sciences, Tirupati during September, 2016 to February, 2018. The study was approved by the Institute Research Council and the Ethics Committee. Written and informed consent was obtained from all the participants in the study.

All the patients of chronic pancreatitis who were planned for surgical management were included. Patient demographics, history and physical examination findings were recorded. Preoperative imaging findings of transabdominal ultrasound (USG), contrast-enhanced computerized tomography (CECT) abdomen and Magnetic Resonance Cholangiopancreatography (MRCP) were noted accordingly. Pancreatic function testing was done preoperatively and postoperatively at 3 months to assess both the exocrine and endocrine functional status of pancreas. Patients were followed up till 3 months following surgery.

\section{Exocrine function assessment}

For exocrine function assessment, fecal fat globule testing was done to assess steatorrhea seen in patients of chronic pancreatitis. This is a qualitative test and it correlates well with quantitative measurement of fecal fat excretion. $^{7}$

\section{Endocrine function assessment}

Endocrine function of pancreas was assessed using glycated hemoglobin (HbA1C), fasting plasma glucose (FPG), Insulin and pancreatic C-peptide levels both preoperatively and also at 3 months after surgery.

FPG $\geq 100$ or $\leq 126$ and/or HbAlc $\geq 5.7$ but $\leq 6.5$ (without anti-diabetic treatment) was considered as prediabetes. FPG $>126$ or HbAlc $>6.5$ was considered as diabetes, provided the measurements are in this range on two separate occasions. $^{8}$ If either FPG or $\mathrm{HbAlc}$ were ele- vated, the test that proved to be high will be repeated on a different day. If the patient is already a known case of diabetes and on anti-diabetic medication, the concerned medicine(s) was discontinued for at least 24 hours (in consultation with the treating endocrinology team) in case of oral medications and at least 12 hours for intermediate acting or mixed short and intermediate acting insulin, before estimating FPG, insulin and C-peptide.

Assessment of C-peptide levels avoids the limitations inherent in measurements of serum insulin levels like variable hepatic extraction and peripheral clearance of insulin. Therefore, In addition to insulin levels, pancreatic $\mathrm{C}$-peptide level is used as measure of beta cell secretion from pancreas. ${ }^{9}$ The C-peptide assay was done using enzyme-linked immunosorbent assay (ELISA) technique. The reference range of C-peptide noted was $0.8-3.1 \mathrm{ng} / \mathrm{ml} .^{10}$

Using FPG and fasting insulin, percentage (\%) beta cell function by homeostatic model assessment (HOMA) was determined using web based calculator. The HOMA Calculator uses the HOMA2 model to estimate beta cell function $(\% \mathrm{~B})$ and insulin sensitivity $(\% \mathrm{~S})$ for an individual from simultaneously measured fasting plasma glucose and fasting plasma insulin values. The HOMA2 model was calibrated to give $\% \mathrm{~B}$ and $\% \mathrm{~S}$ values of $100 \%$ in normal young subjects when using a suitable insulin assay. ${ }^{11}$

\section{Pain and quality of life (QOL) assessment}

Pain and QOL assessment was done using Short form survey (SF-36) questionnaire and Izbicki pain scores respectively at preoperative period and at one month and three months following surgery. ${ }^{12}$ Izbicki score is specific and is based on the pain attack frequency, visual analogue score (VAS), analgesic use, and the duration of disease related inability to work. $^{13}$

\section{Statistical analysis}

Continuous variables (expressed as mean \pm SD) like FPG, insulin, c-peptide and \% beta cell function, were compared between baseline and 3 months after surgery by the paired $t$-test. Categorical variables like proportion of patients with prediabetes or diabetes were compared using Chi-squared test. Comparison of Izbicki pain scores and quality of life between preoperative and postoperative patients was done using repeated measures of analysis of variance (ANOVA) test. Statistical analysis was done us- 
ing SPSS software version 20. The $p$-value $<0.05$ was considered significant.

\section{RESULTS}

Among 35 patients included in the study, 24 patients were males with male to female ratio of $3: 1$. Mean age of the patients included in the study was 35 years (range 10-58 years). Endocrine insufficiency was diagnosed in 17 patients at presentation. History of alcohol consumption was noted in 19 patients and 24 patients were smokers. Mean body mass index of patients was $21.16 \mathrm{~kg} / \mathrm{m}^{2}$. Mean pancreatic duct diameter among the patients in the study was $9.16 \pm 3.12 \mathrm{~mm}$. Complications associated with chronic pancreatitis were observed in 7 patients. Most common was biliary stricture noticed in 3 patients. Among 35 patients in the study, lateral pancreaticojejunostomy was performed in 28 patients and Frey's procedure in 7 patients. Postoperative course was uneventful in all except one patient who required prolonged stay due to bronchiectasis.

On exocrine function assessment, 11 (32\%) patients were noted to have exocrine insufficiency in the postoperative setup among which the number of de novo insufficiencies was $3(8 \%)$ patients. Compared to preoperative exocrine insufficiency noted in $8(23 \%)$ patients, this was found to be statistically significant worsening of exocrine function status in patients of chronic pancreatitis following surgery. Endocrine insufficiency was noted in 13 (37\%) patients postoperatively compared to 17 (49\%) patients preoperatively. Comparison of overall preoperative and postoperative endocrine status of patients showed only clinically improved endocrine status following surgery but not statistically significant $(p=0.74)$, as shown in Table 1 .
Among the endocrine parameters compared between preoperative and postoperative patients at 3 months following surgery, only $\%$ beta-cell sensitivity using insulin was found to be statistically significant $(62.4 \pm 39.7$ vs. $43.2 \pm 17.1$; $p=0.004$ ), as shown in Table 2 .

Izbicki score, used for pain assessment, showed remarkably lower score at 3 months postoperatively $(29.3 \pm 14.3)$ compared to the mean Izbicki score preoperatively $(60.6 \pm$ $12.06)$ and also at 1 month postoperatively (45.76 \pm 10.55$)$ $(p<0.05)$. All the components of SF-36 score were significantly improved in the postoperative period at 1 and 3 months compared to preoperative score except emotional wellbeing component. Therefore, QOL at 3 month following surgery for chronic pancreatitis was significantly better than preoperative QOL $(50.24 \pm 22.16$ vs. $69.48 \pm$ $20.81 ; p<0.05)$, as shown in Table 3 .

\section{DISCUSSION}

This study was performed to evaluate the status of pancreatic function, quality of life and pain status following surgery for chronic pancreatitis. The actual impact of sur-

Table 1. Comparison of preoperative and postoperative endocrine status of patients

\begin{tabular}{lccc}
\hline \multicolumn{1}{c}{ Patients } & $\begin{array}{c}\text { Preoperative } \\
(\mathrm{n}=35)\end{array}$ & $\begin{array}{c}\text { Postoperative } \\
(\mathrm{n}=35)\end{array}$ & $p$ value* \\
\hline Prediabetes & $6(17 \%)$ & $7(20 \%)$ & 0.74 \\
$\begin{array}{l}\text { Diabetes } \\
\begin{array}{c}\text { Non-diabetic } \\
\text { patients }\end{array}\end{array}$ & $17(49 \%)$ & $13(37 \%)$ & \\
Total & $35(100 \%)$ & $15(43 \%)$ & \\
\hline
\end{tabular}

*Chi-squared test

Table 2. Comparison of preoperative and postoperative endocrine parameters of the patients

\begin{tabular}{lccc}
\hline \multicolumn{1}{c}{ Parameter } & $\begin{array}{c}\text { Pre-operative values } \\
(\text { Mean } \pm \text { SD) }\end{array}$ & $\begin{array}{c}\text { Post-operative values } \\
\text { (Mean } \pm \text { SD) }\end{array}$ & $p$ value* \\
\hline HbA1C $(\%)$ & $7.13 \pm 2.65$ & $6.74 \pm 2.03$ & 0.18 \\
FPG $(\mathrm{mg} / \mathrm{dl})$ & $106.5 \pm 33.6$ & $115.06 \pm 32.8$ & 0.21 \\
Insulin $(\mu \mathrm{IU} / \mathrm{L})$ & $5.48 \pm 5.22$ & $3.73 \pm 1.64$ & 0.057 \\
$\mathrm{C}-$ peptide $(\mathrm{ng} / \mathrm{ml})$ & $1.42 \pm 1.6$ & $1.48 \pm 0.8$ & 0.79 \\
$\%$ Beta - cell function using Insulin* & $62.4 \pm 39.7$ & $43.2 \pm 17.1$ & 0.004 \\
$\%$ Beta - cell function using c-peptide* & $82.6 \pm 53.13$ & $77.8 \pm 40.8$ & 0.52 \\
Insulin resistance & $1.11 \pm 1.23$ & $1.16 \pm 0.65$ & 0.77 \\
\hline
\end{tabular}

*Paired $t$-test 
Table 3. Comparison of quality of life parameters (SF - 36 questionnaire)

\begin{tabular}{|c|c|c|c|c|}
\hline $\begin{array}{l}\text { Quality of life } \\
\text { components } \\
\text { (SF-36) }\end{array}$ & $\begin{array}{c}\text { Preoperative } \\
(\text { Mean } \pm \text { SD })\end{array}$ & $\begin{array}{c}\text { Postoperative } \\
1 \text { month } \\
(\text { Mean } \pm \text { SD })\end{array}$ & $\begin{array}{l}\text { Postoperative } \\
3 \text { months } \\
(\text { Mean } \pm \mathrm{SD})\end{array}$ & $p$ value* \\
\hline Physical functioning & $65.71 \pm 22.16$ & $69.85 \pm 22.07$ & $81.7 \pm 18.86$ & $<0.05$ \\
\hline $\begin{array}{l}\text { Role limitation due to } \\
\text { physical problems }\end{array}$ & $39 \pm 30.33$ & $44.5 \pm 32.34$ & $61.51 \pm 29.45$ & 0.007 \\
\hline $\begin{array}{l}\text { Role limitation due to } \\
\text { emotional problems }\end{array}$ & $38.87 \pm 24.51$ & $45.65 \pm 31.67$ & $58.25 \pm 30.31$ & 0.02 \\
\hline Energy & $53.28 \pm 17.73$ & $59.28 \pm 15.20$ & $66.22 \pm 14.66$ & 0.004 \\
\hline Emotional wellbeing & $57.37 \pm 22.54$ & $65.02 \pm 19.81$ & $65.45 \pm 17.69$ & 0.17 \\
\hline Social functioning & $66.54 \pm 28.97$ & $73.11 \pm 16.53$ & $80.3 \pm 16.79$ & 0.03 \\
\hline Pain & $32.48 \pm 19.18$ & $54.54 \pm 16.73$ & $74.91 \pm 21.28$ & $<0.05$ \\
\hline General health & $48.71 \pm 11.9$ & $62.14 \pm 13.68$ & $67.51 \pm 17.50$ & $<0.05$ \\
\hline Total SF-36 score & $50.24 \pm 22.16$ & $59.26 \pm 21.00$ & $69.48 \pm 20.81$ & $<0.05$ \\
\hline
\end{tabular}

*Repeated measures ANOVA test

gery for chronic pancreatitis on pancreatic function is still a matter of debate. Findings of studies on outcomes of pancreatic function by Sakorafas et al. ${ }^{14}$ and Izbicki et al. ${ }^{15}$ have reported varied results. Study on pancreatic drainage procedures in chronic pancreatitis by Prinz et al. ${ }^{16}$ inferred preservation of pancreatic function following drainage procedures like longitudinal pancreaticojejunostomies.

Most of the patients in the present study underwent lateral pancreaticojejunostomy. Only seven patients underwent Frey's procedure in view of bulky head of pancreas on imaging. For the same reason, the effect of type of surgery on outcomes of patients was not assessed in the present study as most of the surgeries were drainage procedures. The results of exocrine function status in the present study showed worsening of exocrine function following surgery. Postoperatively de novo exocrine insufficiency was noted in three patients. None of these three patients with de novo exocrine insufficiency underwent Frey's procedure. This finding in the present study did not correlate with results of previous studies involving drainage procedures. ${ }^{16}$ Büchler et al. ${ }^{17}$ reported decline in exocrine function following pancreatoduodenectomy. In the study on impact of drainage procedures, Nealon and Thompson ${ }^{18}$ showed delayed loss of exocrine and endocrine function following surgery.

In the present study, due to intricacies in glucose metabolism, subtle alterations in endocrine function were identified. Assessment of beta cell function and insulin resistance using HOMA2 calculator is the unique feature of the present study. Even though HbAlc values were slightly better in the postoperative patients, this did not reach statistical significance. Among endocrine parameters assessed, only $\%$ beta cell sensitivity using insulin was significantly lower in postoperative patients. This could be explained due to decrease in number of functioning $\beta$ cells postoperatively. However, possibility of this parameter being influenced by exogenous insulin administration, in spite of spacing insulin administration before testing, cannot be ruled out. Even though the number of patients with diabetes declined among postoperative patients, this did not reach statistical significance. Based on the findings in the present study, only clinical improvement in endocrine status of patients following surgery can be concluded. As most of the patients in the present study underwent drainage procedure, these findings can be generalised to patients undergoing drainage procedure predominantly. Izbicki et al. ${ }^{19}$ reiterated that endocrine function did not worsen in chronic pancreatitis patients who underwent a drainage procedure. Prinz et al. ${ }^{16}$ reported deterioration in endocrine function after a drainage procedure. However, long term follow up, in the present study, would have added more inputs about the exact status of the pancreatic function following surgery. This can be considered as limitation of the present study.

In the present study, Izbicki score, used for pain assessment, showed significant reduction of score in the chronic pancreatitis patients following surgery. Negi et al. ${ }^{20}$ assessed pain relief following Frey's procedure for chronic pancreatitis using Izbicki score and observed that the me- 
dian pain score was reduced from 46.4 to $10.0(p<0.001)$ with partial or complete pain relief in 75 percent of patients. The findings in the present study correlated with findings of study by Negi et al. ${ }^{20}$ All the components of SF-36 score, for QOL assessment, were significantly improved in the postoperative period at 1 and 3 months compared to preoperative score except emotional wellbeing component. Therefore, QOL following surgery for chronic pancreatitis was significantly better than preoperative QOL. A study by Pothula et al. ${ }^{21}$ also observed similar findings of improved QOL following surgery for chronic pancreatitis.

Significant pain relief and improvement in quality of life was noted among patients of chronic pancreatitis following surgery. However, worsening of exocrine function with only clinical improvement of endocrine function was also noted in patients following surgery for chronic pancreatitis.

\section{CONFLICT OF INTEREST}

The authors declare that they have no competing interest.

\section{ORCID}

Pagadala Naga Balaji Nitesh https://orcid.org/0000-0002-9522-7149

Vutukuru Venkatarami Reddy: https://orcid.org/0000-0001-8075-4483

Sivarama Krishna Gavini: https://orcid.org/0000-0002-8862-6977

Suresh Vaikkakara: https://orcid.org/0000-0002-9563-6874

Chandramaliteeswaran Chandrahasan: https://orcid.org/0000-0003-4909-7360

Musunuru Bramheswara Rao: https://orcid.org/0000-0002-8869-8241

Dasari Varun: https://orcid.org/0000-0003-0483-4953

\section{AUTHOR CONTRIBUTIONS}

Conceptualization: PNBN, VVR, SKG, SV. Data curation: PNBN, VVR, SKG, SV, CC. Formal analysis: PNBN, VVR, SKG, SV, DV, MBR. Methodology: PNBN, VVR, SKG, SV, CC, DV. Project administration: PNBN,
VVR, SKG, SV, CC. Visualization: PNBN, VVR, SKG, CC. Writing - original draft: PNBN, VVR, SKG, SV, CC, MBR, DV. Writing - review \& editing: PNBN, MBR, DV.

\section{REFERENCES}

1. Ammann RW, Heitz PU, Klöppel G. Course of alcoholic chronic pancreatitis: a prospective clinicomorphological long-term study. Gastroenterology 1996;111:224-231.

2. Ebbehøj N, Svendsen LB, Madsen P. Pancreatic tissue pressure: techniques and pathophysiological aspects. Scand J Gastroenterol 1984;19:1066-1068.

3. Bockman DE, Buchler M, Malfertheiner P, Beger HG. Analysis of nerves in chronic pancreatitis. Gastroenterology 1988;94: 1459-1469.

4. Tandon RK, Sato N, Garg PK; Consensus Study Group. Chronic pancreatitis: Asia-Pacific consensus report. J Gastroenterol Hepatol 2002;17:508-518.

5. Latifi R, McIntosh JK, Dudrick SJ. Nutritional management of acute and chronic pancreatitis. Surg Clin North Am 1991;71:579595.

6. Williamson RC, Cooper MJ. Resection in chronic pancreatitis. Br J Surg 1987;74:807-812.

7. Fine KD, Ogunji F. A new method of quantitative fecal fat microscopy and its correlation with chemically measured fecal fat output. Am J Clin Pathol 2000;113:528-534.

8. The Expert Committee on the Diagnosis and Classification of Diabetes Mellitus. Report of the Expert Committee on the Diagnosis and Classification of Diabetes Mellitus. Diabetes Care 1997;20:1183-1197.

9. Waldhäusl W, Bratusch-Marrain P, Gasic S, Korn A, Nowotny $\mathrm{P}$. Insulin production rate following glucose ingestion estimated by splanchnic C-peptide output in normal man. Diabetologia 1979; 17:221-227.

10. Appendix: normal hormone reference ranges. In: Gardner DG, Shoback D, eds. Greenspan's basic \& clinical endocrinology. 9th ed. New York: McGraw-Hill, 2011.

11. Levy JC, Matthews DR, Hermans MP. Correct homeostasis model assessment (HOMA) evaluation uses the computer program. Diabetes Care 1998;21:2191-2192.

12. Ware JE Jr, Sherbourne CD. The MOS 36-item short-form health survey (SF-36). I. Conceptual framework and item selection. Med Care 1992;30:473-483.

13. Bloechle C, Izbicki JR, Knoefel WT, Kuechler T, Broelsch CE. Quality of life in chronic pancreatitis--results after duodenumpreserving resection of the head of the pancreas. Pancreas 1995; 11:77-85.

14. Sakorafas GH, Farnell MB, Farley DR, Rowland CM, Sarr MG. Long-term results after surgery for chronic pancreatitis. Int $\mathrm{J}$ Pancreatol 2000;27:131-142.

15. Izbicki JR, Bloechle C, Knoefel WT, Kuechler T, Binmoeller $\mathrm{KF}$, Broelsch CE. Duodenum-preserving resection of the head of the pancreas in chronic pancreatitis. A prospective, randomized trial. Ann Surg 1995;221:350-358.

16. Prinz RA, Greenlee HB. Pancreatic duct drainage in 100 patients with chronic pancreatitis. Ann Surg 1981;194:313-320.

17. Büchler MW, Friess H, Müller MW, Wheatley AM, Beger HG. Randomized trial of duodenum-preserving pancreatic head resection versus pylorus-preserving Whipple in chronic pancreatitis. Am J Surg 1995;169:65-69; discussion 69-70.

18. Nealon WH, Thompson JC. Progressive loss of pancreatic function in chronic pancreatitis is delayed by main pancreatic duct 
decompression. A longitudinal prospective analysis of the modified puestow procedure. Ann Surg 1993;217:458-466; discussion 466-468.

19. Izbicki JR, Bloechle C, Knoefel WT, Rogiers X, Kuechler T. Surgical treatment of chronic pancreatitis and quality of life after operation. Surg Clin North Am 1999;79:913-944.

20. Negi S, Singh A, Chaudhary A. Pain relief after Frey's procedure for chronic pancreatitis. Br J Surg 2010;97:1087-1095.

21. Pothula Rajendra VK, Sivanpillay Mahadevan S, Parvathareddy SR, Nara BK, Gorlagunta Ramachandra M, Tripuraneni Venkata AC, et al. Frey's pancreaticojejunostomy in tropical pancreatitis: assessment of quality of life. A prospective study. World J Surg 2014;38:3235-3247. 